\title{
Issues at the Rural-Urban Fringe: Florida State Laws Related to Land Use ${ }^{1}$
}

Rodney L. Clouser and Michael T. Olexa ${ }^{2}$

EDIS fact sheet FE549 (Issues at the Rural-Urban Fringe: Land Use Conflicts), addressed three broad categories of conflicts: noise, odor, and related issues; infrastructure concerns; and property rights and wealth distribution issues. This fact sheet is a companion commentary that specifically reviews state laws passed in Florida directly or indirectly related to land use on the rural urban fringe.

The statutes addressed in this publication generally cover some of the major rural-urban land conflict issues. Issues related to noise, odor, etc. are addressed directly or indirectly by the Florida Right-to-Farm Act and Agricultural Lands and Practices Act. Distribution of wealth issues are addressed in the Agricultural Lands Classification and Assessment and Private Property Rights Protection. Issues related to infrastructure are addressed by the State Comprehensive Plan and the Local Government Comprehensive Planning and
Land Development Act. Property owners in Florida need to be familiar with these laws.

Material covered in this fact sheet should not be considered an all-encompassing review of state laws related to land use, but rather a review of some of the more significant laws impacting land use. Laws covered in this article can be reviewed and studied in depth and all are found in current Florida Statutes.

\section{Addressing Nuisance Issues}

Some issues facing the rural urban fringe deal with "nuisances" such as noises and odors related to agricultural production.

\section{Florida Statute 823.14: Right-to-Farm Act}

One reason that Florida adopted the right-to-farm law was "that agricultural activities conducted on farm land in urbanizing areas are potentially subject to lawsuits based on the theory of

1. This is EDIS document FE550, a publication of the Department of Food and Resource Economics, Florida Cooperative Extension Service, Institute of Food and Agricultural Sciences, University of Florida, Gainesville, FL. This document is one of a series entitled "Issues at the Rural Urban Fringe". Published May 2005. Please visit the EDIS website at http://edis.ifas.ufl.edu.

This paper is distributed with the understanding that the authors are not engaged in rendering legal advice and the information contained herein should not be regarded or relied on as a substitute for professional advice. This paper is not all-inclusive in providing information to achieve compliance with laws and regulations governing land management. For these reasons, the use of these materials by any person constitutes an agreement to hold harmless the authors, the Institute of Food and Agricultural Sciences, the Agricultural Law Center, and the University of Florida for any liability claims, damages, or expenses that may be incurred by any person as a result of reference to or reliance on the information contained in this publication.

2. Rodney L. Clouser, Professor and Public Policy Specialist, Department of Food and Resource Economics; and Michael T. Olexa, Professor and Director, Agricultural Law Center, Department of Food and Resource Economics, and Member, the Florida Bar; Florida Cooperative Extension Service, Institute of Food and Agricultural Sciences, University of Florida, Gainesville, FL.

The Institute of Food and Agricultural Sciences (IFAS) is an Equal Opportunity Institution authorized to provide research, educational information and other services only to individuals and institutions that function with non-discrimination with respect to race, creed, color, religion, age, disability, sex, sexual orientation, marital status, national origin, political opinions or affiliations. U.S. Department of Agriculture, Cooperative Extension Service, University of Florida, IFAS, Florida A. \& M. University Cooperative Extension Program, and Boards of County Commissioners Cooperating. Larry Arrington, Dean 
nuisance and that these suits encourage and even force the premature removal of the farm land from agricultural use. It is the purpose of this act to protect reasonable agricultural activities conducted on farm land from nuisance suits" [823.14(2)]. Basically the statute establishes that any farm in operation for at least one year, that was not a nuisance when established, using generally accepted agricultural principles, cannot be considered a nuisance unless certain specific conditions exist. Among those conditions are items such as improperly treated human waste, garbage, dead animals, harmful gases, diseased animals dangerous to human health (except animals kept in accordance with a current state or federal disease control program), unsanitary animal slaughter creating potential harmful diseases, etc. The statute specifically notes that change of ownership; type of farm product produced; changing conditions around the farm; or changes to comply with best management practices at local, state, or federal levels do not constitute a nuisance. Typical farm operations defined in the statute are "the marketing of produce at roadside stands or farm markets; the operation of machinery and irrigation pumps; the generation of noise, odors, dust, and fumes; ground or aerial seeding and spraying; the application of chemical fertilizers, conditioners, insecticides, pesticides, and herbicides; and the employment and use of labor." Rules related to the establishment or expansion of farm operations are also covered in the law.

The Florida Legislature also specifically noted that "notwithstanding any other provision of law, a local government may not adopt any ordinance, regulation, rule, or policy to prohibit, restrict, regulate, or otherwise limit an activity of a bona fide farm operation on land classified as agricultural land pursuant to $\S 193.461$ if such activity is regulated through implemented best management practices, interim measures, or regulations developed by the Department of Environmental Protection, the Department of Agriculture and Consumer Services, or a water management district and adopted under Chapter 120 as part of a statewide or regional program; or if such activity is expressly regulated by the United States Department of Agriculture, the United States Army Corps of Engineers, or the United States Environmental Protection Agency."
The lone exception to this area of legislative intent is for lands associated with a farm operation "within a wellfield protection area as defined in any wellfield protection ordinance adopted by a local government, and the adopted best-management practice or interim measure does not specifically address wellfield protection, a local government may regulate that activity pursuant to such ordinance."

\section{Florida Statute 163.3162: Agricultural Lands and Practices Act}

This statute is closely related and duplicates many of the issues addressed in the Florida Right-to-Farm Act. Specific language and policy in $\S$ 163.3162 regarding definitions of farm operations, duplication of regulations, and farm operations within a wellfield protection area are identical. This act does provide for an exception for Miami-Dade County that allows for "ordinances, regulations, or other measures to comply with the provisions of $\S$ 373.4592 or which are necessary to carrying out a county's duties pursuant to the terms and conditions of any environmental program delegated to the county by agreement with a state agency." Statute 373.4592 specifically addresses the Everglades improvement and management and allows Miami-Dade County to further enact local laws to carry out this mission, as well as environmental agreements delegated to the county by state agencies in management of the Everglades. The Agricultural Lands and Practices Act also slightly deviates from Right-to-Farm Act $\S 823.14$ by using definitions of farm and animal products found in $\S 581.011$. Finally, this statute specifically states that counties enacting ordinances regulating transportation and land application of "domestic wastewater residuals or other forms of sewage sludge shall not be deemed to be duplication of regulation." In other words, enacted county ordinances covering these topics are not considered duplication of state legislation.

\section{Florida Statute 604.006: Mapping and Monitoring of Agricultural Lands Act}

This statute requires the Department of Community Affairs (DCA) to develop a program to map and monitor agricultural lands in Florida; to make the information available to agencies, local, state and regional government bodies; and to provide 
technical assistance to these agencies and units of local government in utilizing the data. The intent of the legislation is to establish, if available, agricultural land in the state is declining and the amount of the decline in acreage. Data sources to be used in the mapping and monitoring effort are identified and include information from federal, state, and local government agencies, including information developed and maintained by state universities. DCA is directed to "encourage all state, regional, and local agencies and units of government to utilize the information which is compiled pursuant to this section, as well as the information of the individual agencies from which the compilation of the department is drawn, in planning and other activities in order to minimize the impact of governmental decisions and actions on the continued use and availability of land for agriculture."

\section{Addressing Distribution of Wealth Issues}

\section{Florida Statute 70.001: Private Property Rights Protectoin Act}

This act is also known and referred to as the "Bert J. Harris, Jr., Private Property Rights Protection Act." The private property rights protection act was adopted because the Legislature recognized "that some laws, regulations, and ordinances of the state and political entities in the state, as applied, may inordinately burden, restrict, or limit private property rights without amounting to a taking under the State Constitution or the United States Constitution." The Legislature further intended this act to cover issues outside the normal legal proceedings related to "taking" of property and provide relief or compensation when new laws or regulations by government entities unfairly impacts real property. This legislation specifically exempted the United States and its governmental agencies from liability and relates only to Florida local, regional, and state governments or other state organizations exercising governmental authority. The law is built around societal and legal concepts that real property (land and improvements) is often restricted or limited in its use and the property owner is denied reasonable use or investment returns, or that the property owner is required to bear a disproportionate share of the cost associated for the good of the public (inordinate burden).

The property owner is required to seek action within one year after the law or regulation imposing the inordinate burden is applied to the property. The law requires the property owner to present a claim seeking compensation to the governmental body at least 180 days prior to filing their action under $\S$ 70.001. During the 180-day notice period (unless extended by all parties), the governmental body is required to offer a written settlement to bring closure to the action filed by the property owner. Settlement offers can include adjusting land development or permit standards, increasing or modifying density or use, transfer of developmental rights, land swaps and exchanges, purchase of the real property, or no changes. If a settlement is not reached during this period and all administrative remedies are exhausted, the property owner can file a claim for compensation in circuit court. Property owners must be careful though, because the statute allows the prevailing party in the legal action to claim reasonable costs and attorney fees.

\section{Florida Statute 193.461: Agricultural Lands Classification and Assessment Act}

This statute is commonly referred to as the state's "greenbelt" law. The statute requires county property appraisers to classify and assess land either as agricultural or nonagricultural based on the property's use as of January 1, each year. Florida was an early adopter of this law (second in the United States). One of the theories behind adoption by the state was that land taxed at earning value, rather than market value, would be less likely to convert from agricultural use to other uses. A landowner can, via this act, appeal a property appraiser's denial to classify land as agricultural. Land receiving agricultural classification by the property appraiser, through the appeal process or through a court with jurisdiction, retains the classification in future years or until the "agricultural use of the land is abandoned or discontinued, the land is diverted to a nonagricultural use, or the land is reclassified as nonagricultural pursuant" according to other criteria established in the statute. Additionally, the statute defines "bona fide agricultural purpose" since only 
these lands are eligible for agricultural classification. Some of the characteristics identified defining land as "good faith commercial agricultural use" include the length of time the land has been utilized in agriculture if the use has been continuous; the amount paid for purchase of the property; and if accepted, the commercial agricultural practices used on the property.

\section{Addressing Infrastructure Issues}

\section{Florida Statutes 186.007, 186.008, and 186.009: State Comprehensive Planning Act}

The entirety of Chapter 186 is also often referred to as the "Florida State Comprehensive Planning Act of 1972." Three sections are discussed herein (Florida Statute 186.007: State Comprehensive Plan, Preparation, Revision; 186.008: State Comprehensive Plan, Revision, Implementation; 186.009: Growth Management Portion). This act requires the Executive Office of the Governor to prepare a proposed state plan. Specifically, the proposed plan is to "analyze the problems, opportunities, and needs associated with growth and development in this state, particularly those problems, opportunities, and needs related to land use, water resources, and transportation system development" [186.007(2)]. Additionally, the plan proposed must include infrastructure and capital outlay needs for the state. The growth management portion of the state comprehensive plan is required to address many elements related to the state's growth. Some of the required elements of the growth management section of the plan include identifying metropolitan and urban growth centers; integrating state policy for future growth as it relates to land development, air quality, transportation, and water resources; providing guidelines for determining where urban growth is appropriate and should be encouraged; and promoting land acquisition programs for natural resource protection, open space needs, urban recreational opportunities, and water access [186.009 (2)]. The growth management section specifically notes that the state plan is not to include a land use map. In odd-numbered years no later than October 1, the Governor must recommend to the state Administration Commission (Governor, Attorney General, Chief Financial Officer and the
Commissioner of Agriculture and Consumer Services) proposed plan revisions. By December 15 of the same year, the Administration Commission, after appropriate notice and opportunity for comment, including amendments approved by the Administration Commission, must submit the proposed plan to the Florida Legislature. Chapter 186.008 (3) further states "amendments, revisions, or updates to the plan shall be adopted by the Legislature as a general law." To fully understand the act, individuals need to be familiar with the entire law that can be found in $\S \S 186.001-186.031$ and 186.801-186.901.

\section{Florida Statute 163.3161: Local Government Comprehensive Planning and Land Development Regulation Act}

The clear intent of the act is stated in $\S$ 163.3161(3) "its adoption is necessary so that local governments can preserve and enhance present advantages; encourage the most appropriate use of land, water, and resources consistent with the public interest; overcome present handicaps; and deal effectively with future problems that may result from the use and development of land within their jurisdictions. Through the process of comprehensive planning, it is intended that units of local government can preserve, promote, protect, and improve the public health, safety, comfort, good order, appearance, convenience, law enforcement and fire prevention, and general welfare; prevent the overcrowding of land and avoid undue concentration of population; facilitate the adequate and efficient provision of transportation, water, sewerage, schools, parks, recreational facilities, housing, and other requirements and services; and conserve, develop, utilize, and protect natural resources within their jurisdictions." The growth management act applies to all counties and municipalities in Florida, such as the Reedy Creek Improvement District (Walt Disney World). The act requires local governments to "designate and by ordinance establish a 'local planning agency' unless the agency is otherwise established by law" [163.3174(1)], and gives them the responsibility to oversee the planning process and recommend changes in the plan over time to the county or municipal governing body. 
The local comprehensive plan was required to include a capital improvement element, a future land use plan element, a traffic circulation element, a sewer, solid waste, drainage, potable water and groundwater recharge element, a conservation element, a recreation and open space element, a housing element, a coastal management element for coastal counties and municipalities, and an intergovernmental coordination element [163.3177]. The Department of Community Affairs is charged with the review of local comprehensive plans to determine compliance and consistency with the state and regional plans. The Legislature further stated the intent that "public facilities and services needed to support development shall be available concurrent with the impacts of such development," and that "public facilities and services, unless already available, are to be consistent with the capital improvements element of the local comprehensive plan or guaranteed in an enforceable development agreement" [163.3177 10(h)]. Additional intent related to land use specifically noted rural lands and states that "the local government comprehensive plans and plan amendments adopted pursuant to the provisions of this part provide for a planning process which allows for land use efficiencies within existing urban areas and which also allows for the conversion of rural lands to other uses, where appropriate and consistent with the other provisions of this part and the affected local comprehensive plans, through the application of innovative and flexible planning and development strategies and creative land use planning techniques, which may include, but not be limited to, urban villages, new towns, satellite communities, area-based allocations, clustering and open space provisions, mixed-use development, and sector planning" [163.3177 11(b)].

It is further noted in the act (163.3177 11(d)2)

DCA "shall encourage participation by local governments of different sizes and rural characteristics in establishing and implementing rural land stewardship areas. It is the intent of the Legislature that rural land stewardship areas be used to further the following broad principles of rural sustainability: restoration and maintenance of the economic value of rural land; control of urban sprawl; identification and protection of ecosystems, habitats, and natural resources; promotion of rural economic activity; maintenance of the viability of Florida's agricultural economy; and protection of the character of rural areas of Florida." The act states that rural land stewardship areas may be multi-county, must consist of an area of at least 10,000 acres and "be located outside of municipalities and established urban growth boundaries, and shall be designated by plan amendment" [163.3177 11(d)4].

The plan must be reviewed at local, regional and state levels before adoption by the local government body by a majority of the government body present. Before adopting and transmitting the plan to the state, the local governing body must advertise and hold two public hearings. Amendments to the local plan can only be made twice per year except for special circumstances, including small-scale development activities (10 acres individually and 120 acres cumulatively for local governments with designated urban infill and redevelopment and downtown revitalization areas) [163.3187(c)]. The local government comprehensive planning act requires an adopted evaluation plan and an appraisal report every seven years. The local planning agency is charged with completion of this task, as well as making recommendations to the local governing body regarding adoption of the report. The report is reviewed by appropriate regional and state agencies, and the local governing body must adopt the report either by resolution or ordinance. The state determines if the local plan is appropriate. Once this is completed the local government must amend the local plan and has 18 months to complete this task unless extended for an additional six months by the state.

This discussion of local comprehensive planning just touches the surface of the law and to be completely informed an individual needs to study $\S \S$ 163.2511-163.3246 in depth.

\section{References}

Clouser, Rodney L. 2005. Issues at the Rural Urban Fringe: Land Use Conflicts. Electronic Data Information Source (EDIS) FE549. Department of Food and Resource Economics, University of Florida, Gainesville, FL. http://edis.ifas.ufl.edu/FE549. 
Council of State Government's website. Visted

May 2005.

http://www.csg.org/CSG/Policy/

agriculture+and+rural+policy/rural+policy/

default.htm.

Florida Senate's website. Visited May 2005.

http://www.flsenate.gov/Statutes/

index.cfm?Mode $=$ View\%20Statutes $\&$ Submenu $=1 \& \mathrm{~T}$

$a b=$ statutes. 